\title{
Stealing and Holding Stolen Goods
}

\author{
Fatemeh Sajedi ${ }^{1} \&$ Majid Shaygan Far $^{1}$ \\ ${ }^{1}$ Department of Law, IAU, Mashhad, Iran \\ Correspondence: Fatemeh Sajedi, Department of Law, IAU, Mashhad, Iran. Tel: 98-90-1629-6706. E-mail: \\ fathimasajedi@gmail.com
}

Received: March 11, 2015 Accepted: August 4, 2015 Online Published: August 18, 2015

doi:10.5539/ass.v11n22p133

URL: http://dx.doi.org/10.5539/ass.v11n22p133

\begin{abstract}
The aim of this study was to investigate personal and social dimensions of prisoners and committed crimes such as theft, robbery, burglary, and stick-up in Mashhad City. The statistical sample of the study incudes the prisoners of Mashhad Prison in 2013. The participants for this study were 5500 Iranian prisoners, sentencing for crimes such as theft, robbery, burglary, and stick-up and handling stolen goods. In order to carry out the study, available documents and characteristics of prisoners were used. In order to see to what extent characteristics of prisoners were congruent with their committed crimes, prisoners were grouped based on their social statuses such as their marital status, sex ratio, educational level, and occupational status. As well, the quantitative data were subjected to a set of statistical analyses. Data analysis indicates that old adults have the lowest proportion of stealing crimes at 5 percent and the highest proportion of crime is 38\% (under age 22). What is clear is the impact of marital and educational status on stealing crimes. That is, $70 \%$ of prisoners are single, $16 \%$ of convicts are divorce and $14 \%$ of married prisoners are charged of stealing crime. As well, this research shows that $90 \%$ of offenders are under diploma and over $80 \%$ are unemployed. This study suggests by concluding that social characteristics of prisoners are strong factors and they are worth of paying serious attention. In fact, economic and social development can decrease crime rates. Social development is a reality and an urgent need. It can create new opportunities for all individuals in welfare, education, and crime prevention. It seems that Iran as a developing country requires an essential change in infrastructure, education and interactions. To do this, exploring the social dimensions of individuals and their needs enable policy makers to build better future.
\end{abstract}

Keywords: theft, robbery, burglary, stick-up, Mashhad city

\section{Introduction}

Iran tries to act in accordance with Islamic law. According to the Article four of the Islamic Republic of Iran's Constitution: "all civil, penal, financial, economic, administrative, military and political laws shall be based on the Islamic standards (Habibzadeh, 2006). And criminal law as a part of Islamic law defines a certain set of conditions for a crime to be considered a stealing (theft). Under Islamic Law, Stealing (theft) is considered a Hadd crime, where a specific and fixed punishment is administered (Gouda, 2014). According to Scaros (2011), punishments not only threaten all convicts but also inform all individuals not to act up again. In fact, Islam tries to prevent all people from criminal acts and secure the society. So, negative consequence of crime does not let offenders commit the crime. Deterrence factor of crime is considered as an important case. The primary objective of Islamic penal system is to protect society from the dangers of crime. Society must be protected from the activities of criminals and hoodlums. Social life must be peaceful and devoid of insecurity. The severity of Islamic penal system is aimed at discouraging criminal behavior. If the criminal knows the anguish and pains he will bring to himself, he/she may abstain from committing the crime (Okon, 2014). Stealing and its kinds are ominous crimes that Iranian Government reacts to them strongly and does not tolerate any social disorder. Judiciary system is also serious and shows a backlash against this crime. And Iranian people do hate these convicts and help police to detect offenders. They ask police, judiciary system and government to punish lawbreakers seriously. In Iran Penal Code, the Theft Act 197, stealing is the taking of another person's property underfoot. Because it was ambiguous, judges get into trouble due to other crimes such as robbery and stick-up. For this reason, New Penal Code solved this problem and Theft Act 296 indicates that stealing is the taking of person's property belonging to another (Akbari, 2014). According to Iran Penal Code, the Theft Acts 197 and 296, stealing (theft) is the taking of another person's property and it is also the taking of person's property belonging to another without permission. 
The following acts, Acts 198, 199, 200, and 201, concern with its punishment and enforcement ways of prove (Tehran Judiciary, 2013). Robbery is also the crime of seizing property through violence or intimidation. A perpetrator of a robbery is a robber. Because violence is an ingredient of most robberies, they sometimes result in the harm or murder of their victims. Robbery is generally an urban crime (zarrokh, 2007). As well, a person is guilty of burglary: (a) he enters any building or part of building as a trespasser and with intent to steal, inflict grievous bodily harm, or commit rape therein, or to do any unlawful damages to the building or anything therein, or (b) having entered as a trespasser, he steals or attempts to steal or inflicts or attempts to inflict any grievous bodily harm. As well, a person is guilty of holding stolen goods if (otherwise than in the course of stealing), knowing or believing them to be stolen, he dishonestly receives the goods, or dishonestly undertakes or assists in their retention, removal, disposal, or realization by or for the benefit of another person, or if he arranges to do so (Ramezani, 2009). Stick-up is also a robbery that is done using a gun (Merriam-Webster, 2015). Robbery that leads to injury by the offender consists of three months to ten years of imprisonment and 74 lashes. And according to Article 652, the offender will be sentenced to death penalty (Qisas) in some severe cases (Habibzadeh, 2006). On the other hand, Possession of stolen goods is a crime in which an individual has bought, been given, or acquired stolen goods some other way, other than they themselves having stolen them (Wikipedia, 2015). Receiving, keeping and arranging to receive stolen goods are unforgivable $\sin$ in Iran. It is a criminal offence that an offender will be sentenced from 6 months to 3 years.

In the legal system of Iran, stealing and relevant crimes have received sentences in Chapter V of the Panel Code. Additionally, in some other laws varying forms of stealing including robbery, burglary, and stick-up were also predicted. In the legal system of Iran, following from Islamic jurisprudence reserves Muslims properties the same as Muslims' blood, stealing (theft) is a crime and different punishments have been clarified. According to the current Iranian legal system, stealing divides into four general groups. First: stealing punished by Hadd (Articles 197 onwards of Islamic punishment approved in 1991). Second: specific stealing (Tazir Law approved in 1996). Third: stealing without Hadd punishment but causes chaos in social order or threaten citizens (Articles 203 of Islamic Punishment). Fourth: simple stealing punished by Hadd (Articles 661 of Tazir Law approved in 1996). Participation in stealing and exchange of stolen properties are sentenced in Articles 655 and 662 of Tazir law approved in 1996 (Shekarpour \& Nejad, 2015). Accorrding to Holy Quran, Hadd crime is exactly that for which punishment is divinely sanctioned (Shahidullah, 2014).

In general, Iran is intransigent on crimes such as theft, robbery, burglary, and stick-up and offenders will be sentenced for theft, robbery and burglary from 3 month to 10 years and stick-up is an unforgivable crime that death is its punishment (Zahedi, 2013). According to Iranian Students' News Agency (2015), Special teams of police keep track of records (stealing crimes) and insist on detecting, reacting, and arresting law breakers. One of their duties is to bring back offenders to crime scene to calm people down and to reduce people's anger.

Therefore, the aim of this study is to investigate some aspects of stealing such as theft, robbery, burglary, stick-up, and holding stolen goods. It aims at exploring whether characteristics of prisoners are congruent with their committed crimes.

\section{Method}

The specific objective of this study was to study the social characteristics of prisoners based on stealing crimes in Mashhad City. The statistical sample of the study incudes the prisoners of Mashhad in 2013. Although available documents and characteristics of prisoners were used, it was not possible to interview 5500 prisoners. In fact, the subject access time was limited to available documents.

\subsection{Participants}

The participants for this study were 5500 Iranian prisoners. The majority of offenders were male and young that was charged with stealing crime and its relevant crimes. They ranged in age from 18 to 60 and most of them had not completed university education.

\subsection{Instruments}

In order to carry out the study, available documents and characteristics of prisoners were used. Analysis and conclusion were based on them. The Tables display the descriptive statistics on variables for all prisoners.

\subsection{Procedure}

The data was provided by 5500 prisoners of Prison. In fact, the quantitative data was subjected to a set of statistical analyses. 


\subsection{Data Analysis}

In order to see to what extent characteristics of prisoners were congruent with their committed crimes, prisoners were grouped based on their social statuses such as their marital status, sex ratio, educational level, and occupational status. As well, the quantitative data was subjected to a set of statistical analyses.

\section{Results and Discussion}

This research examines crimes related to stealing in Mashhad city. This part concerns with the results and analysis of data that are driven from available documents. Table 1 shows the population of Mashhad in 2013. It is evident that the population of males is equal to the population of females approximately.

Table 1. Population of Mashhad city

\begin{tabular}{llll}
\hline District & Number & Male & Female \\
\hline 1 & 176104 & 85714 & 90390 \\
2 & 485833 & 242648 & 243185 \\
3 & 322018 & 161265 & 160753 \\
4 & 244944 & 122566 & 122378 \\
5 & 168876 & 84461 & 84415 \\
6 & 253963 & 126940 & 127023 \\
7 & 206968 & 104618 & 102350 \\
8 & 94040 & 46505 & 47535 \\
9 & 300246 & 147934 & 152312 \\
10 & 264523 & 132522 & 132001 \\
11 & 192223 & 100543 & 91680 \\
12 & 39636 & 20169 & 19467 \\
13 & 16884 & 8714 & 8170 \\
Total & 2766258 & 1384599 & 1381659 \\
\hline
\end{tabular}

According to Center of SMDF (2013), population of Mashhad city was 2766258. Mashhad is one of the biggest cities in Iran. In general, $50.1 \%$ of the citizens are males and the rest relate to females. They are fairly evenly distributed across the city.

Table 2 demonstrates the amount of stealing crime and holding stolen goods. To Iranian people, stealing crimes such as theft, robbery, burglary, and stick-up are unforgivable and offenders should be punished seriously. They are blameworthy of doing wrong in the society. On the other hand, individuals who hold stolen goods deserve censure or condemnation.

Table 2. Number of convicts

\begin{tabular}{lll}
\hline Case & Stealing & Holding stolen goods \\
\hline Number & 5470 & 30 \\
\hline
\end{tabular}

As can be seen in the Table, 5470 persons are accused of stealing and its relevant crimes. And 30 persons are guilty of holding stolen goods.

The Table 3 indicates that the convicts are between ages 18-60.

Table 3. Sex ratio

\begin{tabular}{lllll}
\hline Sex & $\begin{array}{l}\text { Male } \\
\text { Stealing }\end{array}$ & Holding stolen goods & $\begin{array}{l}\text { Female } \\
\text { Stealing }\end{array}$ & Holding stolen goods \\
\hline Age & & & & \\
$18-22$ & 2065 & 1 & 17 & 0 \\
$23-35$ (young adults) & 1945 & 10 & 80 & 0 \\
$35-45$ (mature adults) & 994 & 10 & 100 & 0 \\
$46-60$ (old adults) & 266 & 9 & 3 & 0 \\
Total & 5300 & 30 & 200 & 0 \\
\hline
\end{tabular}


Table 3 shows that old adults have the lowest proportion of stealing crimes at 5 percent and the highest proportion of crime is $38 \%$ (under age 22). More than half of stealing crimes are committed by young and mature adults. Sex difference in crime shows that delinquent criminal acts are higher for men. According to Rowe, Vazsonyi, and Flannery (1995), criminal acts are lower for women than men across many different actions and women commit less delinquent acts than men.

It can be seen from Table 4 that $70 \%$ of prisoners are single, $16 \%$ of convicts are divorce and $14 \%$ are charged of stealing crimes. The findings indicate that crimes such as robbery, burglary, and stick-up are not committed by women. Theft crime suggests a weak link may exist between women and their socio-economic status. On the other hand, the lowest rate of crimes shows that there is a social security and control in the society.

A change in criminal behavior may occur in response to the attachment or social bond that forms as a result of marriage. This notion reflects a classical social control or "social bonding" perspective (Hirschi, 1969). The below Table indicates crimes such as theft (T), robbery (R), burglary (B), stick-up (S), and holding stolen goods $(\mathrm{H})$ by males and females.

Table 4. Marital status

\begin{tabular}{|c|c|c|c|c|c|c|c|c|c|c|}
\hline \multirow{2}{*}{ Case } & \multicolumn{5}{|l|}{ Male } & \multicolumn{5}{|c|}{ Female } \\
\hline & $\mathrm{T}$ & $\mathrm{R}$ & B & $\mathrm{S}$ & $\mathrm{H}$ & $\mathrm{T}$ & $\mathrm{R}$ & B & $\mathrm{S}$ & $\mathrm{H}$ \\
\hline Married & 650 & 20 & 1 & 2 & 20 & 43 & 0 & 0 & 0 & 0 \\
\hline Single & 3400 & 400 & 7 & 3 & 5 & 65 & 0 & 0 & 0 & 0 \\
\hline Divorced & 700 & 80 & 4 & 3 & 5 & 92 & 0 & 0 & 0 & 0 \\
\hline
\end{tabular}

Table 4 shows that the majority of crimes are committed by single males. Women are less accused of these crimes. Crimes such as robbery, burglary, and stick-up are not committed by women and divorced females committed theft crimes too. Married men are guilty of holding stolen goods. This is evident that marital status has influence on these crimes and the social tie of marriage is important because it creates interdependent systems of obligation, mutual support, and restraint that impose significant costs for translating criminal propensities into action (Sampson, Laub, \& Wimber, 2006).

Educational level can have effect on crime. Because education leads to significant changes in behavioral patterns and interaction with others. Table 5 shows stealing crimes by males and females.

Table 5. Educational level

\begin{tabular}{|c|c|c|c|c|c|c|c|c|c|c|}
\hline \multirow{2}{*}{ Case } & \multicolumn{5}{|c|}{ Male } & \multicolumn{5}{|c|}{ Female } \\
\hline & $\mathrm{T}$ & $\mathrm{R}$ & B & $\mathrm{S}$ & $\mathrm{H}$ & $\mathrm{T}$ & $\mathrm{R}$ & B & $\mathrm{S}$ & $\mathrm{H}$ \\
\hline - Diploma & 4000 & 480 & 10 & 8 & 25 & 150 & 0 & 0 & 0 & 0 \\
\hline Dpl-BA & 750 & 20 & 2 & 0 & 5 & 50 & 0 & 0 & 0 & 0 \\
\hline$+\mathrm{BA}$ & 0 & 0 & 0 & 0 & 0 & 0 & 0 & 0 & 0 & 0 \\
\hline
\end{tabular}

Table 6. Occupational status

\begin{tabular}{lllllllllll}
\hline \multirow{2}{*}{ Case } & Male & & \multicolumn{7}{c}{ Female } & \\
& $\mathrm{T}$ & $\mathrm{R}$ & $\mathrm{B}$ & $\mathrm{S}$ & $\mathrm{H}$ & $\mathrm{T}$ & $\mathrm{R}$ & $\mathrm{B}$ & $\mathrm{S}$ & $\mathrm{H}$ \\
\hline Unemployment & 3496 & 396 & 11 & 8 & 23 & 150 & 0 & 0 & 0 & 0 \\
Self-employment & 1246 & 96 & 1 & 0 & 23 & 45 & 0 & 0 & 0 & 0 \\
Clerk & 0 & 0 & 0 & 0 & 0 & 5 & 0 & 0 & 0 & 0 \\
\hline
\end{tabular}

The Table 5 demonstrates that the majority of males are illiterate (under diploma) and 150 female convicts are charged of theft crime. These rates show that educational level is important and is also a strong factor. There are many reasons to expect that education reduces crime. By raising earnings, education raises the opportunity cost of crime and the cost of time spent in prison. Education may also make individuals less impatient or more risk averse, further reducing the propensity to commit crimes (Lochner \& Moretti, 2003).

Table 6 shows crimes such as theft (T), robbery (R), burglary (B), stick-up (S), and holding stolen goods (H) by 
males and females and occupational statuses of convicts.

Table 6 shows that $70 \%$ of male prisoners and $70 \%$ women convicts are unemployed. It indicates that unemployment is associated with more stealing crimes and serious attentions should be paid to unemployment case. Occupational status correlates with less crime. High frequency of changing jobs and unemployment for a person correlate with criminality. In fact, there is a relationship between low incomes, percentage under the poverty line, few years of education, and high income inequality in an area and more crime in the area (Ellis, Beaver, \& Wright, 2009).

The present study examines the characteristics of offenders such as, sex ratio, marital status, occupational status, and educational level and their committed crimes. According to this study, sex difference in crime shows that delinquent acts are higher for men. And more than half of stealing crimes are committed by young and mature adults. Since the main body of the society consists of young and mature adults, serious actions should be taken to help them and to improve life standards. Sex difference is not the only identity that has a relationship with crime rates. Analysis result shows that marital status has influence on stealing crimes and family structure can decrease crime rates. That is, the changes of marital status should consist of shifts from being single to being married. It can be seen from this study that $70 \%$ of prisoners are single, $16 \%$ of convicts are divorce and $14 \%$ of married prisoners are charged of stealing crimes. So, programs should be designed to improve marital status in the society. Another factor that affects stealing crime rate is educational level. Although the prisoners ranged in age from 18 to 60 , most of them had not completed university education. It shows that educational level can have effect on crime. Based on the Table 5, the majority of convicts are illiterate (under diploma). Improving the literacy can give prisoners an opportunity to return to their real positions. In fact, education programs can provide prisoners with a new chance to build their future. In general, education paves the ways for progress. This study indicates that occupational status can play a role in increasing or decreasing the crime rates. Table 6 shows that $70 \%$ of male prisoners and $70 \%$ women convicts are unemployed. It demonstrates that unemployment is associated with more stealing crimes and serious attentions should be paid to unemployment case. According to Maddah (2013), unemployed people are encouraged to commit more stealing crimes and there is significant and positive relationship between unemployment rate and stealing by theft crimes data in Iran's provinces over the period (1997-2006).

The findings of this study place emphasis on personal and social dimensions of offenders. Investigating personal and social dimensions of offenders can help policy makers to improve the life standards and social security. Improving social status of prisoners also plays a centrally important role in preventing re-offending. That is, training is only thing that they need and improve their life levels. Hence, Education programs may make individuals patient or more risk averse and reduce the propensity to commit crimes. Crime is a negative externality with enormous social costs. Given the large social costs of crime, even small reductions in crime associated with education may be economically important (Lochner \& Moretti, 2003). As well, Employment support services and opportunities should be provided equally in justice system. More importantly, employment programs for prisoners can reduce recidivism after release. Marital status has also influence on these crimes and the social tie of marriage is important because it creates interdependent systems of obligation, mutual support, and restraint that impose significant costs for translating criminal propensities into action (Sampson, Laub, \& Wimber, 2006).

\section{Conclusion}

This study was an attempt to investigate whether personal and social dimensions of offenders had influence on their committed crimes such as theft, robbery, burglary, and stick-up. It also sought to find out whether these variables are important factors to reduce crime rates. In order to carry out the study, available documents and characteristics of 5500 prisoners were used. The majority of offenders were male and young that was charged with stealing crime and its relevant crimes. They ranged in age from 18 to 60 and most of them had not completed university education. In order to see to what extent characteristics of prisoners were congruent with their committed crimes, prisoners were grouped based on their social statuses such as their marital status, sex ratio, educational level, and occupational status. The results showed that more than half of stealing crimes are committed by young and mature adults. It can be seen from this study that single and divorced offenders committed more crimes. That is, the changes of marital status have influence on committed crimes. The results also indicated that occupational status has a relationship with crime rates. $70 \%$ of male prisoners and $70 \%$ women convicts are unemployed. It shows that there is a tendency to commit stealing crimes for unemployed offenders. Saridakis and Spengler (2009) showed that there is a significant relationship between unemployment and property crime rates. Moreover, conclusions are drawn on the relationship between social dimensions of prisoners and committed crimes. In summary, this study suggests by concluding that social characteristics of 
prisoners are strong factors and they are worth of paying serious attention. In fact, economic and social development can decrease crime rates. Social development is a reality and an urgent need. It can create new opportunities for all individuals in welfare, education, and crime prevention. It seems that Iran as a developing country requires an essential change in infrastructure, education and interactions. To do this, exploring the social dimensions of individuals and their needs enable policy makers to build better future.

Reducing crime rates is possible by raising the education of potential criminals, improving their marital status, and enhancing their occupational level. Despite the enormous implications, little is known about the relationship between the characteristics of offenders and their committed crimes. So paying special attentions to these variable is worth to secure the society and to bring back the offenders to a normal life. In general, it is inferred that improving social dimensions of offenders can enhance social security and order.

\section{References}

Akbari, A. (2014). Theft punishments. Iran Newspaper. Retrieved from http//www.magiran.com

Ellis, L., Beaver, K. M., \& Wright, J. (2009). Handbook of crime correlates. Academic Press. ISBN 9780123736123.

Gouda, M. (2014). Stealing more is better? An economic analysis of Islamic law of theft. German: Marburg Center for Institutional Economics.

Habibzadeh, M. J. (2006). Legality principle of crimes and punishments in Iranian legal system. Educational Research and Review, 1(3), 108-114.

Hirschi, T. (1969). Causes of delinquency. Berkeley: University of California Press.

Iranian Students'News Agency. (2015). Retrieved from http://www.isna.ir

Lochner, L., \& Moretti, E. (2003). The Effect of education on crime: Evidence from Prison inmates, arrests, and self-reports. Retrieved from http://www.econ.ucla.edu/moretti/papers.htmleml.berkeley.edu/ moretti/ $\operatorname{lm} 46 . p d f$

Maddah, M. (2013). An Empirical Analysis of the Relationship between Unemployment and Theft Crimes. International Journal of Economics and Financial Issues, 3(1), 50-53.

Merriam-Webster Dictionary. (2015). Retrieved from http://www.merriam-webster.com

Okon, E. E. (2014). Hudud punishments in Islamic criminal law. European Scientific Journal, 10(14).

Ramazani, M. (2009). Law text. Tehran: Nasle Nikan Publications.

Rowe, D. C., Vazsonyi, A. T., \& Flannery, D. J. (1995). Sex differences in crime: Do means and within-sex variation have similar causes? Journal of Research in Crime and Delinquency, 32, 84-100. http://dx.doi. org $/ 10.1177 / 0022427895032001004$

Sampson, R., Laub, J., \& Wimber, C. (2006). Does marriage reduce crime? A counterfactual approach to within-individual casual effects. Criminology Journal, 44(3). http://dx.doi.org/10.1111/j.1745-9125.2006. 00055.x

Saridakis, G., \& Spengler, H. (2009). Crime, deterrence and unemployment in Greece: A panel data approach. DIW Berlin: Institute for Economic Research.

Scaros, C. E. (2011). Understanding the constitution. Massachusetts: Jones \& Bartlett Learning.

Shahidullah, Sh. M. (2014). Comparative criminal justice systems: Global and local perspectives. U.S.A: Jones \& Baetllet Learning.

Shekarpour, Y., \& Nejad, M. M. Z. K. (2015). Violent theft: a new concept or an evidence of stealing. VISI J Akademik, 8, 57-63.

Tehran Judiciary. (2013). Retrieved from http://www.ghavanin.ir/detail.asp?id=1232

Wikipedia. (20015). Retrieved from http://en.wikipedia.org

Zahedi, A. (2013). Collection of law. Tehran: Jungle Publications.

Zarrokh, E. (2007). Crimes against the persons. Retrieved from http://ssrn.com/abstract=961355

\section{Copyrights}

Copyright for this article is retained by the author(s), with first publication rights granted to the journal.

This is an open-access article distributed under the terms and conditions of the Creative Commons Attribution license (http://creativecommons.org/licenses/by/3.0/). 